\title{
Inventory and Efforts to Reduce Carbon Dioxide Emissions for the Operation of the Jeneponto Units 1 \& 2 Coal Power Plant in South Sulawesi, Indonesia
}

\author{
Muhammad Nawir ${ }^{1, *}$, Henny Pramoedyo ${ }^{2}$, Bagyo Yanuwiadi ${ }^{3}$, Dan Syarifuddin Nojeng $^{4}$ \\ ${ }^{1}$ Doctoral Program of Environmental Science, Postgraduate School, Universitas Brawijaya, Indonesia \\ ${ }^{2}$ Department of Statistics, Faculty of Mathematics and Natural Science, Universitas Brawijaya, Indonesia \\ ${ }^{3}$ Department of Biology, Faculty of Mathematics and Natural Science, Universitas Brawijaya, Indonesia \\ ${ }^{4}$ Department of Electrical Engineering, Faculty of Engineering, Universitas Muslim Indonesia, Indonesia
}

Received September 28, 2021; Revised January 27, 2022; Accepted February 21, 2022

\section{Cite This Paper in the following Citation Styles}

(a): [1] Muhammad Nawir, Henny Pramoedyo, Bagyo Yanuwiadi, Dan Syarifuddin Nojeng, "Inventory and Efforts to Reduce Carbon Dioxide Emissions for the Operation of the Jeneponto Units 1 \& 2 Coal Power Plant in South Sulawesi, Indonesia," Environment and Ecology Research, Vol. 10, No. 2, pp. 174 - 181, 2022. DOI: 10.13189/eer.2022.100206.

(b): Muhammad Nawir, Henny Pramoedyo, Bagyo Yanuwiadi, Dan Syarifuddin Nojeng (2022). Inventory and Efforts to Reduce Carbon Dioxide Emissions for the Operation of the Jeneponto Units 1 \& 2 Coal Power Plant in South Sulawesi, Indonesia. Environment and Ecology Research, 10(2), 174 - 181. DOI: 10.13189/eer.2022.100206.

Copyright $\bigcirc 2022$ by authors, all rights reserved. Authors agree that this article remains permanently open access under the terms of the Creative Commons Attribution License 4.0 International License

\begin{abstract}
The Jeneponto Steam Power Plant is the largest 2 unit coal-fired power plant in South Sulawesi with a total capacity of 520MW. Unfortunately, this plant emits a large number of greenhouse gases (GHG), especially $\mathrm{CO}_{2}$, which are detrimental to human health. Therefore, this research aims to determine $\mathrm{CO}_{2}$ emissions from 2013-2019 and estimate possible ways to reduce them from 2020-2029 using the mass balance method to link emissions to its sources' activity measurement. The data shows that a total of 12.39 million tonnes of $\mathrm{CO}_{2}$ were emitted from 2013 to 2019. This data was obtained using the Chronological Production Modeling System (PROSYM) software to calculate, analyze and compare the emissions from various types of coal calories used in the Jeneponto Coal-Fired Power Plant. Furthermore, it is estimated that $\mathrm{CO}_{2}$ emission from 2020 to 2029 is likely to reach 31.551 million tonnes. In addition, the coal was replaced from sub-bituminous to bituminous because, according to the technical specifications of the plant, there was a significant reduction in emissions compared to current coal, bituminous with emissions of 30.658 million tons $(\mathrm{EF}=1.02)$, anthracite of 32.069 million tons $(\mathrm{EF}=1.06)$, and lignite of 32.943 million tons $(\mathrm{EF}=1.09)$. However, this is still smaller than the average emission factor standard for coal power plants in Indonesia according to the UNDP study.
\end{abstract}

Keywords Emission Inventory, $\mathrm{CO}_{2}$, SPP, CCS

\section{Introduction}

Electricity plays an essential role in the national development of any country. Therefore, significant efforts need to be made to ensure it meets society's various requirements by building power plants from natural resources, such as coals, water, geothermal, etc. Coal is one of the primary raw materials used as an alternative means of producing energy in Indonesia due to its abundance in nature. According to Ismail J. [4], approximately 4,968 million tons, or $0.55 \%$ of the world's total coal reserves, are found in Indonesia. Therefore, due to the high demand for electricity, through a development program, the government conducted a 35,000 MW through State Electricity Enterprise (PLN) and Private Electricity programs as Independent Power Producers (IPP) and non-IPP third parties from 2015-2019. The product composition is projected in 2028 to be $54.4 \%$ coal, $22 \%$ natural gas (including LNG), 9.6\% geothermal, $10.9 \%$ hydropower, $0.4 \%$ fuel oils, and $2.6 \%$ Renewable Energy, Electricity Supply Business Plan (RUPTL PLN 2019-2028) ${ }^{1}$, as shown in Figure 1. 
Due to the high demand for electrical energy, in November 2012, a Bosowa Energy company built a Steam Power Plant (SPP) in Jeneponto Regency with a capacity of $2 \times 125 \mathrm{MW}$ (Unit 1), using coal as the main fuel. In November 2017, the company upgraded its system by adding a capacity of 2 x $135 \mathrm{MW}$ (Unit 2).

$\mathrm{CO}_{2}$ gas is one of the greenhouse gases (GHG) believed to contribute most to the increase in the earth's average temperature. According to 2012 data obtained by the Ministry of Environment, SPP activities' contribution to air pollutants in carbon dioxide $\left(\mathrm{CO}_{2}\right)$ is $11,279,621$ tons/year. Therefore, to reduce $\mathrm{GHG}$ emissions and follow up on the results of COP-21 negotiations, Indonesia ratified the Paris Agreement through Law No. 16/2016 on the United Nations Framework Convention on Climate Change (UNFCCC). With this ratification, Indonesia is committed to keeping the global temperature rise below $2^{\circ} \mathrm{C}$ and striving to reach $1.5^{\circ} \mathrm{C}$ and net-zero emissions by the middle of this century.

This commitment is embodied in the mitigation and adaptation activity plan stipulated in the Nationally Determined Contribution (NDC) submitted to the UNFCCC. Therefore, through this document, Indonesia is committed to reducing greenhouse gas (GHG) emissions by $29 \%$ using its efforts (unconditional) or $41 \%$ with international assistance (conditional) by 2030. However, when compared to the Business as Usual (BAU) scenario in the form of emissions reduction actions of $29 \%-41 \%$, the energy sector is projected to be the largest contributor to GHG. It currently has a share of $58-71 \%$ of total national emissions, therefore this sector is targeted to reduce emissions by $11-14 \%$ or by approximately 310-398 million tons of $\mathrm{CO}_{2}$ to the BAU scenario in 2030 . Currently, a $41 \%$ reduction from BAU has been achieved, however, the increase in the number of emissions from the energy sector in 2030 is likely to increase three times when compared to the amount of GHG emissions in 2012.

The 2018 report by the Intergovernmental Panel on Climate Change (IPCC) ${ }^{2}$ showed the urgency of reducing GHG emissions in the next decade to ensure the global temperature does not exceed $1.5^{\circ} \mathrm{C}$. According to studies on the $1.5^{\circ} \mathrm{C}$ scenario, global GHG emissions have a significant ability to decrease by $40-50 \%$ (high confidence) in 2030, compared to BAU emissions or the equivalent of 25-30 $\mathrm{Gt} \mathrm{CO}_{2}$ e per year, with net-zero emissions by 2050 .

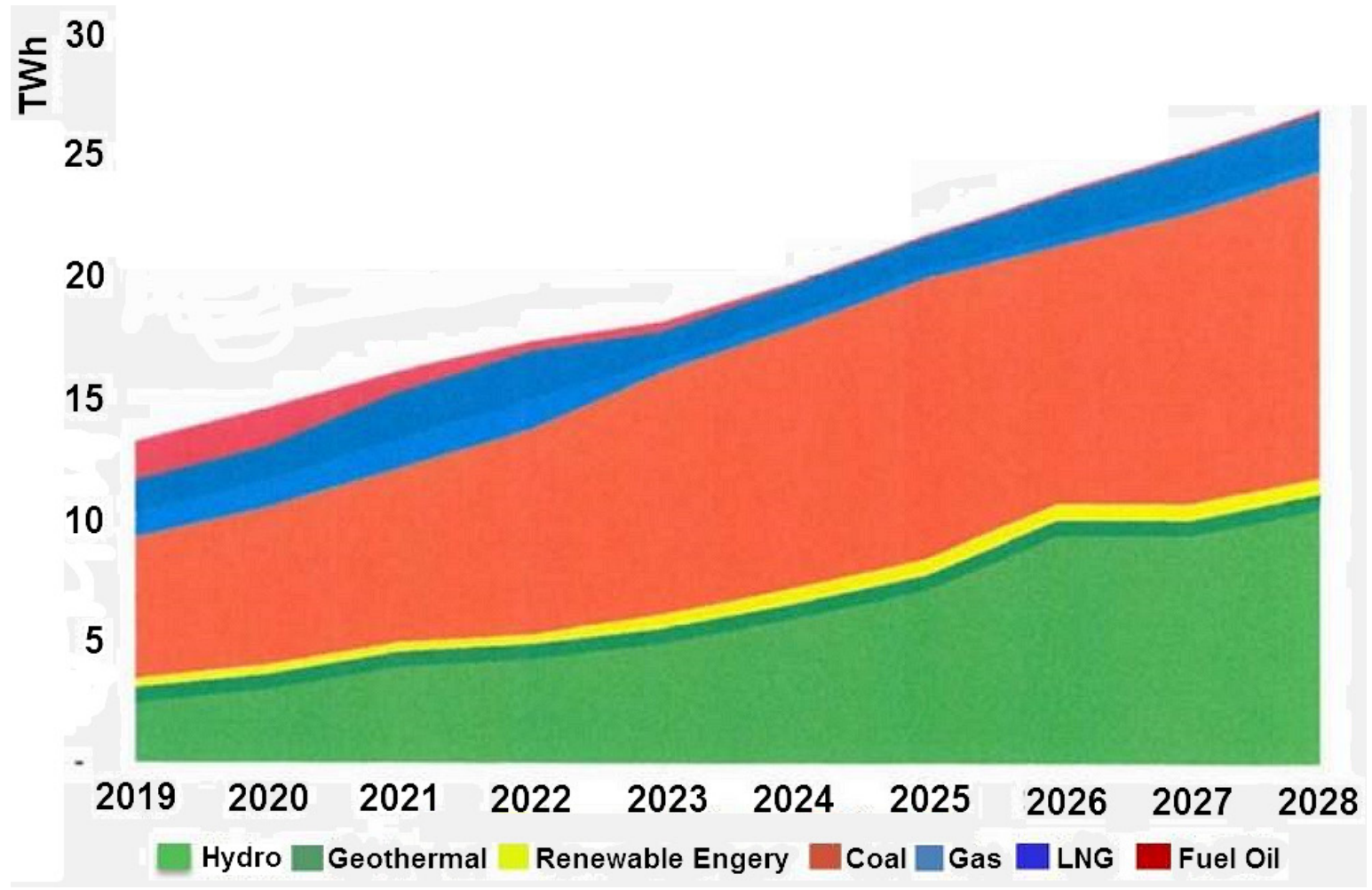

(Source: RUPTL PLN of 2019-2028)

Figure 1. The Composition of the Electric Energy Mix Based on the Indonesian Fuel Type (GWh) 
The Climate Action Tracker (CAT), in its report on Indonesia's NDC, places the country's BAU scenario as highly insufficient and less than $4^{\circ} \mathrm{C}$. This means that assuming all countries in the world follow Indonesia's BAU scenario, $4^{\circ} \mathrm{C}$ of global warming is likely to occur in 2100. The analysis results also assess the possible success of Indonesia to achieve the conditional NDC target. Therefore it is still included in the insufficient category of below $3^{\circ} \mathrm{C}$. This assessment indicates that to fulfill the commitment associated with achieving the temperature target in the Paris Agreement, Indonesia still needs to increase its ambition to mitigate climate change, especially in the energy sector, which dominates the GHG emissions portion 2030 .

The fossil fuel power generation sector is the most significant contributor of Coal-Fired Power Plant with GHG emissions, amounting to 453.2 million tons of $\mathrm{CO}_{2} \mathrm{e}$ or $40 \%$ of the total national emissions in 2010 with various sub-sectors. Efforts that need to be focused on the electricity subsector are due to the following reasons.

1) The majority of Indonesia's electricity sources still come from fossil fuels, especially coal. Data from the Ministry of Energy and Mineral Resources in 2015 [3] showed that electricity generation emissions contributed the most to the energy sector, reaching 175.6 million tonnes of $\mathrm{CO}_{2} \mathrm{e}$ or $67 \%$ of total energy emissions. Coal-fired power plants contributed 122.5 million tonnes of $\mathrm{CO}_{2} \mathrm{e}$ or $70 \%$ of all electricity generation emissions. It is projected to double to 351.3 million tonnes of $\mathrm{CO}_{2}$ e by 2028 , with SPP emissions reaching 301.3 million tonnes or $86 \%$ of the total power plant emissions.

2) Power generation technologies capable of substituting SPP are widely available and increasingly economical. Solar cell and wind power technology have rapidly decreased costs in the last decade. Furthermore, installation on a utility-scale provides a competitive electricity production price against SPP. Therefore, both types of plants are built in relatively fast time (1-2 years). In line with the global trend where investment is associated with renewable energy (solar cells and wind power) has increased significantly. The 2019 IEA report showed that investment in renewable energy increased by $55 \%$ in 2018 compared to 2010 while ignoring the factor of declining prices for renewable energy generation components.

Based on the 2019-2028 RUPTL-PLN [1], PLN (State Electricity Enterprise) plans to build a $27 \mathrm{GW}$ Coal-fired power plant. Therefore, when this plan is fully implemented, the Indonesian SPP's installed capacity is likely to double in the next 10 years. This means that the long-term SPP investment has the ability to operate for 30-40 years. Therefore, Indonesia faces a dilemma between emission reduction targets and economic losses due to SPP assets' utilization (stranded assets) in the future. This condition implies the need to formulate policy steps in minimizing the negative economic and financial impacts that arise in the electricity sector. From several main problems regarding efforts to reduce emissions, an analysis of the pattern of fuel consumption for various types of coal is carried out on the carbon dioxide emissions produced in the period $2019-2028$ based on the forecast for electricity demand in South Sulawesi, using the emission calculation scheme using the mass balance method

\section{Implementation Strategy for Reduction of Coal-Fired Power Plant Emission}

The high demand for economic growth has implications for increased electricity usage. For example, in Indonesia, the electricity consumption rate has increased by approximately $26 \%$ in the last four years, ie, from 812 $\mathrm{kWh}$ per capita in 2014 to $1,021 \mathrm{kWh}$ per capita in 2017. Therefore, the country is significantly dependent on fossil power to fulfill electricity needs, where more than $88 \%$ of electricity comes from fossil fuels, while $60 \%, 22 \%, 6 \%$, and $12 \%$ come from coal, natural gas, oil, and renewable energy, respectively.

Based on the 2019-2028 Electricity Supply Business Plan (RUPTL), coal demand in power plants is estimated to increase from 90 to $150-160$ million tons in 2028-2030. However, over the last four years, this estimate has changed dramatically because the government currently encourages the development of coal-fired power through a 35,000 MW power plant acceleration program (FTP), including the construction of a 22,000 MW coal-fired power plant. Domestic coal consumption is also expected to increase due to a rise in coal consumption per unit of electricity production. According to Ismail et al.[4], the high coal consumption rate in State Electricity Enterprise power plants in the last 15 years was $44 \%$, due to the low efficiency of coal-fired power plants and the use of low-calorie lignite coal types below 4,200 kcal.

The political economy of energy prices also drives the increase in the use of coal in the electricity sector. The government tends to keep electricity affordable for the majority of the population by maintaining the competitiveness of business and industry. In addition, coal is considered the cheapest electricity source compared to other fossil fuels or most renewable energies by policymakers and power generation companies. According to the government, a large portion of coal in the electricity system leads to low costs.

The Indonesian government has made a price control policy for domestic coal production through a Domestic Market Obligation (DMO) policy to keep the electricity production costs of State Electricity Enterprise or Independent Power Producer (IPP) very low in accordance with the price and quality of calories needed.

The numerous activities needed to reduce carbon 
dioxide emissions in the energy sector, especially the Coal-Fired Power Plant, are as follows:

1) Advanced conversion technologies. The use of more modern and efficient technology to reduce the amount of fuel consumed as well as the $\mathrm{CO}_{2}$ emissions per kWh of electricity produced. [5] stated that efforts are made to increase energy consumption efficiency and reduce $\mathrm{CO}_{2}$ emissions through structural adjustments and advances in generation technology within a certain period using the Kyoto standard protocol. Utilization of Advanced Supercritical (ASC) clean coal technology and an Integrated Gasification Combined Cycle (IGCC) are processes used to control carbon dioxide emissions economically with higher efficiency and lower emissions compared to generators [6].

2) Switching to lower-carbon fossil fuels and renewable energy. Coal is the fuel used for power generation and produces the largest emissions. However, the use of gas-fired technology produces $50 \%$ of total emissions compared to coal with relatively zero emissions. The policy associated with closing coal power plant growth with strict emission control leads to balanced and optimal planning as well as coordination between power plants with renewable energy from other alternative sources without emissions [7].

3) Power station rehabilitation. The existing Steam Power Plants operating for a long time tend to utilize the subcritical steam technology, which allows efficiency to be degraded by restoring SPP performance or improving more efficient technology. Furthermore, this process enables the integration of Carbon Capture Sequestration (CCS) technology. Life cycle assessment through emissions capture and store emissions reduction through CCS technology by $72 \%$. Therefore, this method has the ability to reduce carbon dioxide emissions [8]. According to [9], CCS minimizes the cost of carbon dioxide emissions by $64 \%$ for $1000 \mathrm{MW}$ ultra-supercritical plants through the consumption of standard and different coal plants.

This research combined several activities in monitoring, controlling, and tightening $\mathrm{CO}_{2}$ emitters with the principle of balance and fairness in its implementation. Electricity growth and environmental quality are likely to be positive, assuming the two are in line. Conversely, it becomes negative when the $\mathrm{CO}_{2}$ emissions are taken into account in the analysis. Therefore, it needs to be closely monitored based on environmental emission standards by imposing a penalty by applying a carbon tax on $\mathrm{CO}_{2}$ emission polluters [13]. Besides, emission monitoring is carried out through standard, direct measurement, and energy balance methods by applying uncertainty estimation and monitoring with real-time accuracy [14].

Indonesia was declared the largest contributor to national greenhouse gas emissions. This led to numerous efforts to reduce emissions by implementing mitigation strategies in each sub-sector, with the largest source obtained from burning fossil fuels in power plants. Therefore, the increase in the SPP efficiency is used to determine the amount of coal burned. Base on the theory, the efficiency levels of supercritical $(37-40 \%)$ and ultra-supercritical (44 - 46\%) power plants are higher than subcritical technologies $(33-37 \%)$ commonly used in Indonesia. Moreover, the government monitors emissions issued by power plants through the Minister of Environment and Forestry Regulation (PermenLHK) No.15 / 2019 view table 1. This regulation sets the obligation for steam power plants to monitor emissions, including the main parameters, such as $\mathrm{SO}_{2}, \mathrm{NO}_{\mathrm{x}}, \mathrm{PM}$, and $\mathrm{Hg}$, which has to be submitted to the official issuing environmental permits every 3 months (continuous monitoring) or once every 6 months (manual monitoring). The regulation governs the increase in the emission standard for SPPs, especially those built after the effect occurred. Hence, the SPP construction's investment value tends to increase because it is equipped with a more advanced emission control system.

Table 1. The emission-quality standard for Coal-Fired Power Plant based on Minister of Environment and Forestry Regulation (PermenLHK) $15 / 2019$

\begin{tabular}{|c|c|c|}
\hline $\begin{array}{c}\text { Emissin } \\
\text { Quality } \\
\text { Standards }\end{array}$ & Category & $\begin{array}{c}\text { Emission Quality } \\
\text { Standards } \\
\text { (mg/Nm }\end{array}$ \\
\hline NOx & Built after April 2019 & 200 \\
Built before April 2019 & 550 \\
\hline $\mathrm{SO}_{2}$ & Built after April 2019 & 200 \\
& Built before April 2019 & 550 \\
\hline \multirow{2}{*}{$\mathrm{PM}$} & Built after April 2019 & 50 \\
& Built before April 2019 & 100 \\
\hline \multirow{2}{*}{ Mercury } & Built after April 2019 & 0.03 \\
& Built before April 2019 & 0.03 \\
\hline
\end{tabular}

Source: Minister of the Environment Regulation

No.P.15/MENLHK/SET/JEN/KUM.1/4/2019

\section{Methodology}

This research comprises several stages, namely data collection and processing, planning of electric power generation with the Chronological Production Modeling System (PROSYM) software, calculation of emission factors, analysis and comparison of emissions from various types of coal calories used in the Jeneponto Coal-Fired Power Plant view table 2.

Calculation of $\mathrm{CO}_{2}$ emission for power plants needs data associated with the number of documented factors related to emission sources' activity measurement. The calculation used the system balance method, as follows:

Fuel Energy =

Electrical energy generated / Thermal Efficiency

Furthermore, fuel consumption is linked to the Net Calorific Value (NCV) of the coal used: 
Fuel Consumption $=$

Fuel energy / Net Calorific Value

From the combustion results, the emission is obtained as follows:

\section{$\mathrm{CO}_{2}$ Emission $=$}

Fuel consumption $\mathrm{x} \% \mathrm{C}$ of fuel $\mathrm{x}(44 / 12)$
$\mathrm{CO}_{2}$ Emission Factor $=$

$\mathrm{CO}_{2}$ Emission/ Energy generated

In general, the Indonesian coal specification is based on the percentage of carbon and net calorific value, as shown in Table 3.

Table 2. Technical Specifications of the Jeneponto Coal-Fired Power Plant, South Sulawesi

\begin{tabular}{|c|c|c|c|c|c|c|c|}
\hline No & Unit Type & $\begin{array}{c}\text { Electrical } \\
\text { Capacity } \\
\text { (MW) }\end{array}$ & $\begin{array}{c}\text { Calorific Value } \\
\text { (kcal/kg) }\end{array}$ & $\begin{array}{c}\text { Coal Flow } \\
\text { Rate } \\
(\mathbf{k g} / \mathbf{j a m})\end{array}$ & $\begin{array}{c}\text { Boiler } \\
\text { Efficiency } \\
(\mathbf{\%})\end{array}$ & $\begin{array}{c}\text { Thermal } \\
\text { Efficiency } \\
(\mathbf{\%})\end{array}$ & $\begin{array}{c}\text { Turbin Heat } \\
\text { Rate } \\
(\mathbf{k J} / \mathbf{K W h})\end{array}$ \\
\hline 1. & Jeneponto Existing & $2 \times 125$ & 5000 & 66460 & $\geq 91$ & 32.3 & 8520 \\
\hline 2. & Jeneponto Expansi & $2 \times 135$ & 4200 & 80800 & $\geq 83$ & 34,2 & 8230 \\
\hline
\end{tabular}

Source: Coal-Fired Power Plant Spesification 2017

Table 3. Specifications for Indonesian Coal content

\begin{tabular}{|c|c|c|c|}
\hline \multirow{2}{*}{ Coal Type } & \multicolumn{2}{|c|}{ Net Calorivic Value } & \multirow{2}{*}{ \% Carbon } \\
\cline { 2 - 3 } & Joule/kTon & $\mathbf{k W h} / \mathbf{k g}$ & 32.8 \\
\hline Lignite & 11.9 & 3.3 & 49.5 \\
\hline Sub-Bituminous & 18.9 & 5.3 & 66.6 \\
\hline Bituminous & 25.8 & 7.2 & 71.6 \\
\hline Anthracite & 26.7 & 7.4 & \\
\hline
\end{tabular}

Source: Industrial quality and climate policy review agency, Indonesia 2012

\section{Fuel, $133 \quad 0.49 \%$}

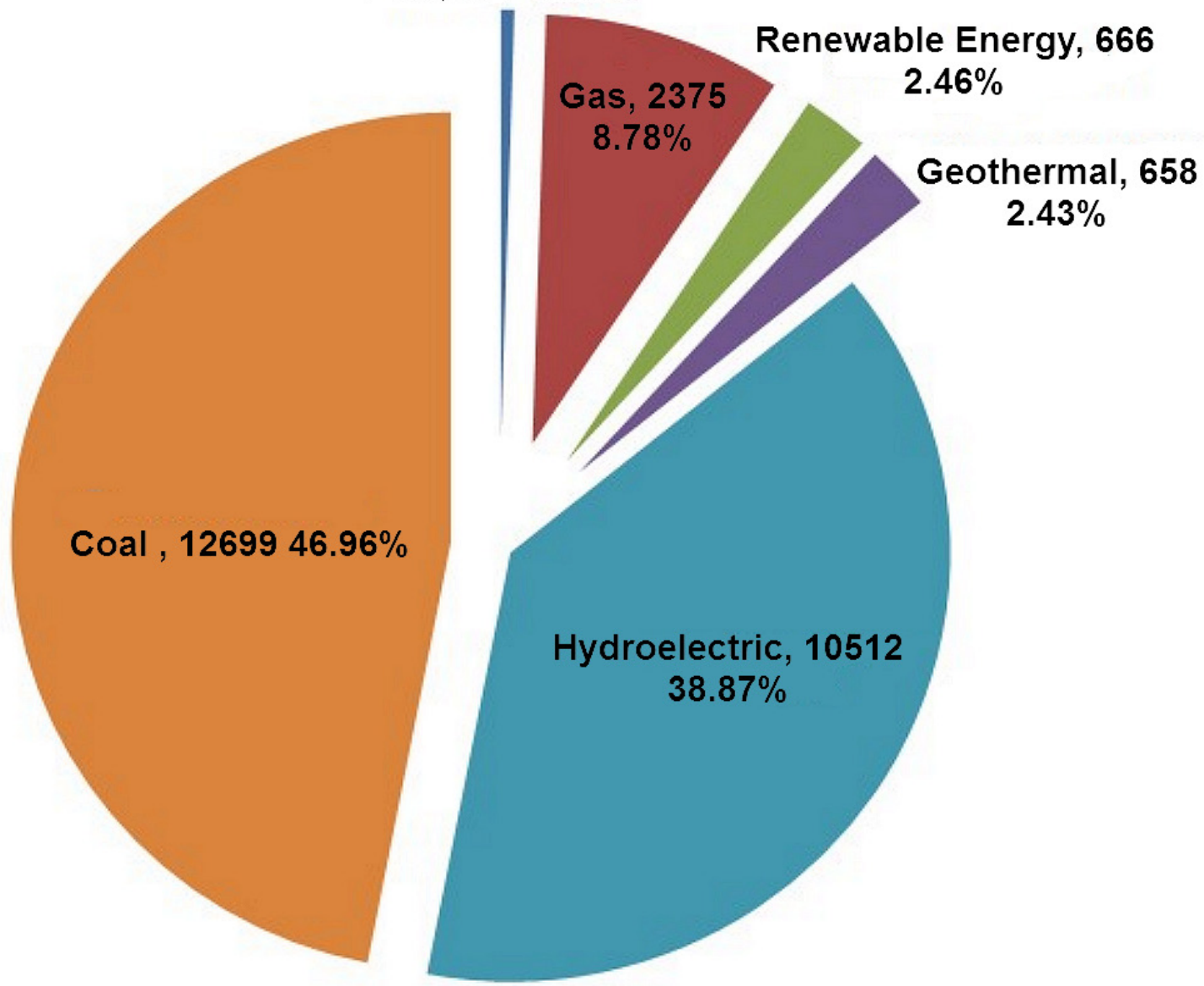

Source: RUPTL PLN 2019 - 2028

Figure 2. Graph of Electrical Energy Production Composition in 2028 based on the type of fuel (GWh) 


\section{Data and Discussion}

The South Sulawesi electricity is an amalgamation of the South and Central regions formed through a $150 \mathrm{kV}$ interconnected system, with a balanced placement plan according to regional balance criteria. Figure 2 shows the Graph of Electrical Energy Production Composition in 2028 based on fuel type (GWh).

Due to the increase in demand for electric power with a significant rise in coal fuel composition, it is projected that carbon dioxide emissions are likely to increase by 1.8 times from 11.1 million tons in 2019 to 20.2 million tons in 2028. Therefore, tremendous efforts are needed to reduce carbon dioxide emissions by prioritizing the addition of generators from water, geothermal energy sources and the development of new and renewable energy.

Coal plays a substantial role in Indonesia's local/regional economy. In the National Energy General Plan (RUEN), it is stated that the coal utilization shifts from the export commodity sector to a domestic source of energy due to development capital. Furthermore, as the largest domestic coal consumer ( $>85 \%)$, SPP currently plays a significant role in coal mining sustainability. In Indonesia, coal is generally based on its caloric value and availability because it contains very high (anthracite) $1 \%$, high (bituminous) 13\%, medium (sub-bituminous) 24\%, and low (lignite) $62 \%$ calories.

The coal used by Jeneponto SPP South Sulawesi is a sub-bituminous type. The amount of coal and diesel as fuel consumed during the start-up process largely fluctuates and requires relatively smaller diesel. Since the development of unit 2 ( $2 \times 135 \mathrm{MW})$, coal consumption has increased in line with a rise in $\mathrm{CO}_{2}$ emissions. Furthermore, as the demand for electric power in the southern part of Sulawesi's electricity system increases, all power plants connected to the $150 \mathrm{kV}$ transmission network operators to meet the demand. Jeneponto SPP, one of the large power plants that support the system, which has been in existence since 2013 (Unit 1) with the addition of Unit 2 in 2018, has caused major problems regarding carbon dioxide emissions, thereby leading to coal combustion. Based on emissions data for 2013 - 2019, the total $\mathrm{CO}_{2}$ emissions produced are 12.396 million tons of $\mathrm{CO}_{2} \mathrm{e}$, with projected values of 31.551 million tons of $\mathrm{CO}_{2} \mathrm{e}$ until 2029 (RUPTL PLN 2019-2028), as shown in Figure 3.

The high emission produced needs the application of Carbon Capture Storage (CCS) technology, comprising of capture, transfer, and post-combustion storage. This technology minimizes the release of emissions through the chimney into the free air. After the $\mathrm{CO}_{2}$ is separated, storage is carried out by injecting it into the ground or under the sea. This storage process has the potential to cause leakage during transfer due to local and global process at global and local risks to humans and the surrounding ecosystem.

Efforts to reduce $\mathrm{CO}_{2}$ emissions are needed by replacing the type of coal used, namely, anthracite, bituminous, or lignite, with varying calorific value and carbon content. Based on mass balance analysis for the type of coal used, it is found that the $\mathrm{CO}_{2}$ emission estimates are significant. Anthracite is the best type of coal with high carbon content and calorific value, which leads to rapid combustion with higher $\mathrm{CO}_{2}$ emissions. Meanwhile, bituminous produces lower $\mathrm{CO}_{2}$ emissions than Sub-bituminous along with higher combustion. However, lignite is in the lowest category, its calorific value and carbon content produce large emissions compared to other types. This is because it generates more electricity per kWh of combustion.

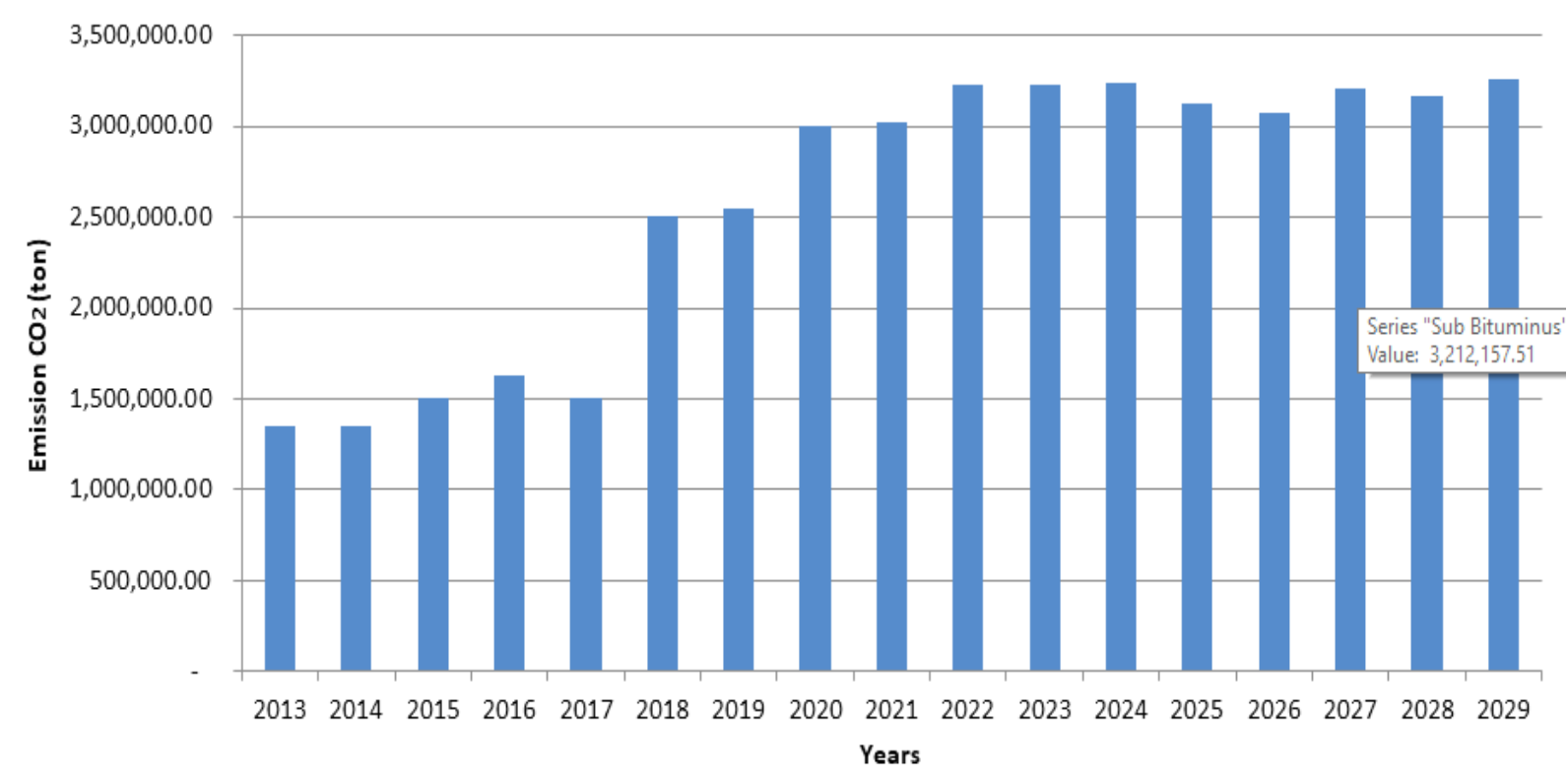

Figure 3. Data Graph and Projection of $\mathrm{CO}_{2}$ Emissions until 2029 


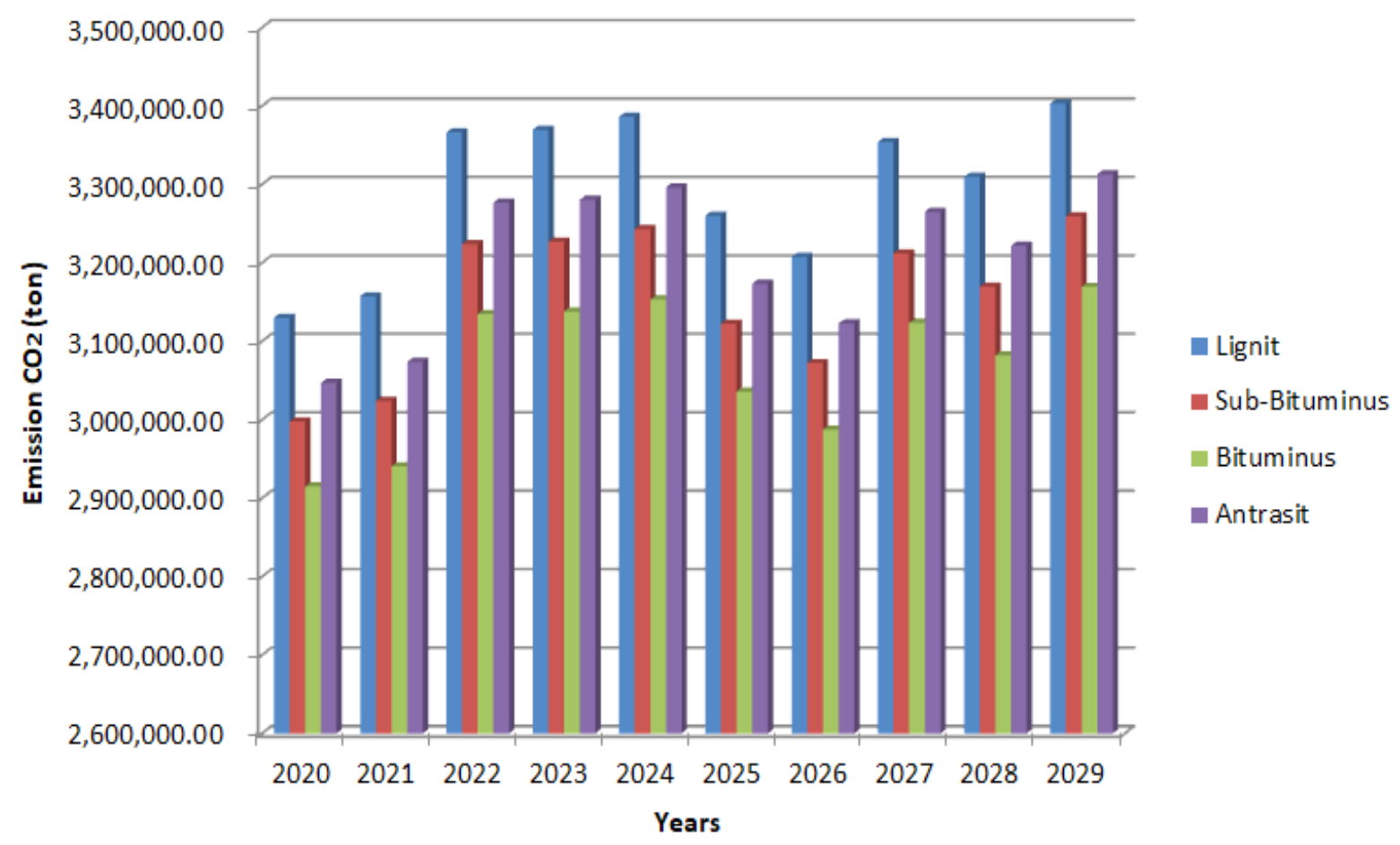

Figure 4. Graph of $\mathrm{CO}_{2}$ emission projection for various types of coal until 2029

The carbon content in the sub-bituminous coal has low Jeneponto SPP values, therefore, it is necessary to replace it with a better type of coal. Based on the mass balance analysis in accordance with the SPP boiler's technical specifications to reduce the $\mathrm{CO}_{2}$ emissions. It is expected to change the type of coal from sub-bituminous to bituminous types to enhance the boiler engine's performance and reduce emissions. Furthermore, the emission factors produced from the four types of coal are Lignite 1.09, Sub-bituminous 1.05, Bituminous 1.02, and Anthracite 1.06 , respectively. Therefore, the bituminous type has the smallest value compared to the SPP standard emission factor of $1.14 \mathrm{~kg} / \mathrm{kWh}$ in Indonesia based on UNDP 2007 [10].

\section{Conclusions}

In conclusion, the total $\mathrm{CO}_{2}$ emission produced by SPP Jeneponto from 2013 to 2019 is 12.396 million tons. However, according to RUPTL - PLN, in the next ten years $(2020-2029)$, this emission is Likely to be around 31.551 million tons. Therefore, with an increase in emissions every year, it is important to apply carbon capture storage technology in order to reduce the post-combustion rate of $\mathrm{CO}_{2}$ using the existing SPP.

Efforts to reduce it can be carried out by replacing coal types with lower emissions, according to the boiler's technical specifications and based on the electricity needs for the next ten years. Furthermore, Lignite has emissions of 32.943 million tons, Sub-bituminous 31.551 million tons, Bituminous 30.658 million tons, and Anthracite 32.069 million tons. This indicates that the type of coal that is better used is Bituminous because of the high heat percentage. Therefore, the combustion process is faster with reduced emission compared to the sub-bituminous coal currently utilized.

When compared with the average SPP emission standard factor in Indonesia, the $\mathrm{UNDP}^{10}$ study is 1.14 , with the results of this research showing the available emission factor of several types of coal available in Indonesia, such as Lignite (1.09), Sub-bituminous (1.05), Bituminous (1.02), and Anthracite (1.06). This implies that the smaller the emission factor, the smaller the result from coal burning will be. Therefore, the type of coal that is good for bituminous is because the electric power produced is proportional to the $\mathrm{CO}_{2}$ emissions released, considering that coal-fired power plants are the largest emitters compared to other fuel-fired power plants such as MFO, HSD, or Natural Gas.

\section{REFERENCES}

[1] PT. PLN (Persero), (2019): Rencana Usaha Penyediaan Tenaga Listrik (RUPTL) PT. PLN (Pesero) 2019-2028, PT. PLN (Pesero), (https://web.pln.co.id/media/siaran-pers/201 9/04/rencana-usaha-penyediaan-tenaga-listrik-atau-ruptl)

[2] Intergovermental Panel on Climate Change (IPCC), 2006 "General Guidance and Reporting" Journal of IPCC Guidelines for National Greenhouse Gas Inventories, chapter 1 page 1.5 . 
[3] Retno Damayanti and Herni Khaerunnisa, 2018 "Carbondioxide Emission Factor Estimation From Indonesian Coal” Indonesian Mining Journal, Vol. 21. N0.1, April 2018 Page 45-58.

[4] C. J. Ismail, A. Reani, N. W. Mondamina and V. Charloth, "Rehabilitation at $2 \times 400 \mathrm{MW}$ Indonesia coal-fired power plant: Emission reduction and cost-effectiveness," 2017 IEEE 7th International Conference on Power and Energy Systems (ICPES), Toronto, ON, Canada, 2017, pp. 117-120, doi: 10.1109/ICPESYS.2017.8215932.

[5] Zhao Y., (2009): Control of $\mathrm{CO}_{2}$ Emissions of China Under Kyoto Protocol, International Conference on Energy and Environment Technology, $32-35$ pp (DOI: 10.1109/ICEET.2009.474).

[6] Li J., Wang F., \& Song H., (2010): Coal Consumption and $\mathrm{CO}_{2}$ Emission Control Technology in China. Asia Pacific Power and Energy Conference IEEE (DOI: 10.1109/APPEEC.2010.5448984).

[7] Yuan J., Na C., Lei Q., Xiong M., Guo J., Hu Z.. (2016): Coal Use for Power Generation in China, Resources Conservation and Recycling. (DOI: 10.1016/j.resconrec.20 16.03.021).

[8] Castelo Branco, D. A., .Moura, M. C. P., Szklo, A., \& Schaeffer, R. (2013) : Emissions Reduction Potential from $\mathrm{CO}_{2}$ Capture: A Life-Cycle Assessment of a Brazilian Coal-Fired Power Plant. Energy Policy 61 1221-1235 pp.
(DOI: 10.1016/j.enpol.2013.06.043).

[9] Yu, S., Zhang, J., \& Cheng J., (2016): Carbon Reduction Cost Estimating of Chinese Coal-Fired Power Generation Units: A Perspective from National Energy Consumption Standard. Journal of Cleaner Production 139612 - 621 pp. (DOI: 10.1016/j.jclepro.2016.08.066)

[10] UNDP., 2007, "Indonesia Microturbine Technology Application Project" United Nation Development Programe, USA., 2007.

[11] BPKIM., (2012): Petunjuk Teknis Perhitungan Emisi Gas Rumah Kaca (GRK) di Sektor Industri, Badan Pengkajian Kebijakan Iklim dan Mutu Industri, (https://kemenperin.go .id/kinerja-industri).

[12] International Energy Agency (IEA), (2014) : Carbon Capture and Storage:The Solution for Deep Emissions Reductions, http://www.iea.org/

[13] McLaughlin, C., Elamer, A. A., Glen, T., AlHares, A., \& Gaber, H. R. (2019). Accounting society's acceptability of carbon taxes: Expectations and reality. Energy Policy, 131(December 2018), 302-311. https://doi.org/10.1016/j.enpol.2019.05.008

[14] Majanne, Y., Korpela, T., \& Uotila, T. (2014). EU Emission Trading Related $\mathrm{CO}_{2}$ monitoring in power plants. In $I F A C$ Proceedings Volumes (IFAC-PapersOnline) (Vol. 19, Issue 3). IFAC. https://doi.org/10.3182/20140824-6-za-1003.02230 